\title{
Neoendogenous Model of Overcoming Imbalances in Economic-legal Framework of Russia Agrarian Regions as a Factor of Economic Security
}

\section{Sergey Aleksandrovich Belousov}

Associate Professor, Theory of State and Law Department, Saratov State Law Academy, Saratov, Russia; Email: belser@mail.ru

\author{
Aleksandr Yurevich Pavlov \\ Associate Professor, Applied Economics Department, Penza State Technological University, \\ Penza, Russia; Email: pavlov_85@bk.ru

\section{Vera Nikolaevna Batova}

Associate Professor, Applied Economics Department, Penza State Technological University Penza, Russia; Email: batova.v.n@yandex.ru

\section{Sergey Borisovich Surovov}

Professor, Department of History, Sociology, Politics and Service, Saratov State Law Academy Saratov, Russia; Email: rector@ssla.ru

\section{Andrey Vladimirovich Kolesnikov}

Associate Professor, Administrative and Municipal Law Department, Saratov State Law Academy Saratov, Russia; Email: kaviras@yandex.ru

\section{Elena Grigorievna Vyushkina}

Associate Professor, Department of the English Language, Theoretical and Applied Linguistics Saratov State Law Academy, Saratov, Russia; Email: vyushkina@ssla.ru

Doi:10.5901/mjss.2016.v7n1p167

\section{Abstract}

Evolution processes acceleration, characteristic for modern development, and complicacy of territorial-economic systems structure and ways of their elements collaboration result in additional prerequisites for genesis of economic-legal imbalances, i.e. disequilibrium states, gaining systematic and long-term character. Imbalance of socio-economic system of Russia agrarian regions reached such scales that it becomes an essential factor of security violation. Transformation processes taking place in Russia agrarian regions in recent decades demanded new approaches to regional development, in particular, applying of neoendogenous models combining endogenous resources and exogenous factors. The article describes basic characteristics of a rural territories sustainable development regional model based on three components: employment of territory endogenous potential, development of social capital and neoendogenous units (local self-government). Special attention is paid to clearing imbalances in economic-legal framework of agrarian regions on the basis of indicative planning application.

Keywords: economic-legal framework imbalance, neoendogenous approach, sustainable development model, agrarian regions, social capital, indicative planning, local self-government, economic security.

\section{Introduction}

Evolution processes acceleration, characteristic for modern development, and complicacy of territorial-economic systems structure and ways of their elements collaboration result in additional prerequisites for genesis of economic-legal imbalances, i.e. disequilibrium states, gaining systematic and long-term character. 
Imbalance of socio-economic system of Russia agrarian regions reached such scales that it becomes an essential factor of security violation. Agrarian regions negative socio-economic development appears in decreasing of rural centers of population number in 2010 by 9.2 thousand villages comparing to 1989. The rural centers of population without inhabitants number increased from 9.4 thousand in 1989 to 19.4 thousand in 2010. In 2010 centers of population with up to 10 inhabitants accounted to 23.7 percent. Reducing of rural population structure results in depopulation and desolation of agrarian regions, disposal of productive lands intended for agriculture, labour potential decrease.

Regional development international experience shows that these problems solution lies in the area of sustainable development conceptual framework implementation (OECD, 2007).

So in accordance with RF Government Regulation № 598 of 15 July 2013 the Federal special purpose programme "Sustainable development of agrarian regions for 2014 - 2017 and for the period up to 2020" was commenced. It includes the following new elements of government policy:

- increasing of living environment comfort level in agrarian regions;

- increasing of agricultural labour status value and developing in the society a positive attitude to rural way of life;

- improvement of demographic situation;

- development of local self-government and civic society institutes in the agrarian regions.

It is necessary to note that from 1991 to the beginning of 2000 the Russian village demonstrated its own particularity of development, determined by contradictory consequences of agrarian sphere reformation, but beginning from 2000-s basic trends of socio-economic changes are similar to world tendencies, in particular the following ones:

- economic differentiation (market specialization of certain regions and territories within globalized economy, crisis of traditional forms of agricultural economy organization);

- increase of importance of non-agrarian employment in rural regions as manifestation of household socioeconomic activities diversification and changes of rural way of life;

- polarization of socio-economic environment, manifesting in territories segmentation in accordance with development type (innovative, retrogressive, etc.) (Mantino, 2008).

\section{Methods and Materials}

In recent decades changes in agrarian regions have resulted in appearing of rural territories development new models. It is necessary to note that there are two approaches to a territory development concept, which differ in understanding of sources and grounds of economic growth.

Endogenous approach proponents insist on the possibility of agrarian development which is based on the internal territory resources - natural, human, and cultural (Ploeg, 2000). In the beginning of the 1990-s endogenous theories authors showed that in models with exogenous (external) factors, in particular scientific-technical progress, there is a shift of notions of scientific-technical knowledge and results of its implementation. Thus, knowledge is noncompetitive and nonexclusive benefits while innovations not only acquire characteristics of competitiveness and exclusivity but also become a stimulus for organization of monopolistic structures in the economy by means of patent protection with the purpose keep an exclusivity characteristic of knowledge which can bring an income. Thereby the role of information as an endogenous factor of an economic growth was shown.

Modern science determines several basic factors, four of which are connected with physical economy ability to grow, with offer and availability of resources:

- quantity and quality of natural resources;

- quantity and quality of labour resources;

- $\quad$ the amount of nominal capital and development level of material sphere businesses;

- availability of technologies and universities.

The factors named above are determinative and principal and belong to internal (endogenous) development factors. They can be easily analysed quantitatively. At the same time economic development is substantially influenced by political and economic institutes, forms and types of property and social relations. A very important role is played by the level of social division and cooperation of labour and manufacture, as well as corresponding economic forms used for realization manufacturing and economical processes (Boudeville, 1966).

Representatives of another point of view (neoendogenous approach) believe that agrarian regions should combine endogenous resources and exogenous processes relying on external support (globalization, foreign commerce, outward investment, state support) (Lowe, 2006). Conceptually neoendogenous development is described on the basis of using material and cultural potential of a region, social capital development and social nets organization stimulated by local 
participatory democracy or local self-government bodies (Cabus and Vanhaverbeke, 2003; Ray, 2001; Ward et al.., 2005).

A neoendogenous development advantage is a combination of determined region resources and creation of characteristic features helping the region 'to sell itself' by means of external opportunities. As a rule, it is based on particular differential quality products such as tourism, gastronomic agricultural goods and food supplies, crafts production, etc. (Cabus, 2001; Cabus and Vanhaverbeke, 2003; Ray, 2001; Ward et al., 2005).

\section{Main Text}

Neoendogenous approach to region development as a whole, and rural territories in particular, is directed at strategic regional potential research and its realization. This approach, to a big extent, corresponds to conditions of new global risks and opportunities, as it is based on the fact that regional factors demonstrate particular forms of coordination of conditions of branch and regional development.

The offered neoendogenous model of agrarian regions sustainable development (figure 1) includes a number of elements functioning within social capital development: endogenous units, local (national) subjects and neoendogenous units.

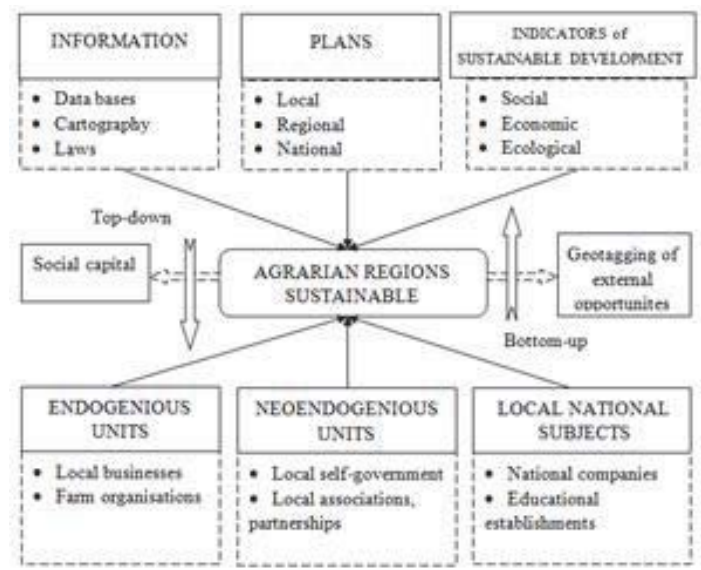

Figure 1 - Neoendogenous model of agrarian regions sustainable development at the regional level (A. Tolon-Becerra, X. Lastra-Bravo, 2009).

Social capital is a notion coined by Pier Bourdieu in 1980 for denomination of social bonds which can be a resource of gaining benefits. According to Bourdieu's concept social capital is exclusively a group resource, which value заключается is included in the possibility of транзакционных издержек decrease (it becomes unnecessary to fix agreements in writing, invite external witnesses) which leads to subjects' benefit increase (Bourdieu, 2000).

An important transfer from quality discussion of social norms importance to more substantive research took place when a Robert Putnam's book "Making democracy work: Civic traditions in modem Italy" was published. Comparing the results of decentralization of authorities in Italy in 1960-s Putnam noticed that northern regions, where people are more active socially, used the received powers more successfully while in 'passive' southern regions the quality of управления decreased (Putnam, Leonardi, Nanetti, 1993).

This proves the importance of model neoendogenous units which may be used as important mediators between endogenous units and local (national) subjects. First of all, they include local authorities and voluntary social organisations, which, having local directions in their activities, опираются on external opportunities and federal program events.

To reach agrarian regions sustainable development it is necessary to have effective local authorities which create conditions for resolving problems characteristic to this locality with the help of special programme instruments because there is no single solution for all regions. But for a neoendogenous model of agrarian development a simple transfer of powers from central government to regional and municipal bodies is not enough. It is necessary to reach a balance 
between local community and the higher level power (Reed, Fraser, and Dougill, 2006; Sucháček and Malinovský, 2007), which satisfies the necessity of a new governing form which allows to take into account initiative "Top-down/Bottom-up" and to evaluate their development potential in accordance with economic, ecological and social potentials of the region (Ashley and Maxwel, 2001; Shucksmith, 2000).

There are many definitions of local self-government. In recent years they are most often connected with the one given in the European Charter of Local Self-Government (ETS N.122, Strasbourg, 1985 г.), which reads as follows "...the right and the ability of local authorities, within the limits of the law, to regulate and manage a substantial share of public affairs under their own responsibility and in the interests of the local population".

Local self-government in the Russian Federation is a people's governance form providing within the limits set in the Constitution of the Russian Federation, Federal laws, and, in cases set by federal laws, Russian Federation subjects laws, independent and self-responsible resolving issues of local importance by the population themselves and/or through the bodies of local self-government relying on the population interests and taking into account historical and other local traditions.

Comparing the definitions once can find a legal imbalance: Russian version speaks about the power of deliberately formed structures while the Charter speaks of authoritative powers of territorial communities which existence determined by objective circumstances.

Moreover, the European Charter declares not only the right but an effective legal capacity of a local community to resolve issues imposed on it. Lack of these words in the Russian definition makes it meaningless because there is no legal capacity without sufficient financial resources and legal basis. Although Federal Law \#131-FL "On general principles of local self-government organization in Russian Federation" tries to resolve this problem, most of the municipal units do not have necessary resources and are not likely to become legally capable if the modern model of their organization stays in force.

For this reason when determining directions of municipal unit territory development it is important to consider the goals which are set up in front of it and the authority matters which are assigned for local self-government bodies in a region. It is this principle that implements the potential that self-government has due to its knowledge of local conditions and governing bodies' dependence on endogenous units.

Endogenous units of the model include, first of all, population, as well as family households, local enterprises, cooperatives, etc. These agents, as a rule, work within a local rural territory.

Local (national) subjects are subjects working both on local (regional) and national (federal) levels: companies, media, universities.

Agrarian regions sustainable development is provided by reaching social and economic stability, planned development of productive forces and social relations, maintenance of conditions for material welfare, intellectual development and social self-realization of a person, preservation and rational usage of environment not harming future generations. As indicators of such development we offer to consider the following:

1. High quality of life of population and security.

2. Rational structure and effective functioning of economics.

3. Sustainable ecological balance.

4. Availability of institutional conditions of social stability and equation.

To build a system of enumerated indicators there used information available for generalization and processing from primary and secondary resources such as bibliographic data bases, administrative registers, maps, etc.

A number of scholars (Hirczak and Mollard, 2004) believe that an indicators system may be chosen and analysed by experts (top-down) but such approach is not objective in a neoendogenous model because participation of local selfgovernment and community representatives (bottom-up) is compulsory, as they correct the list of indicators depending on specificity of territory development (Paus, 2007).

At the same time one of the basic aspects of agrarian regions governance is encouragement of local selfgovernment and community participation in this process (Ashley and Maxwel, 2001; Goodwin, 2003; Shucksmith, 2000; Shortall, 2008).

A recognized instrument of agrarian regions economic-legal system stability governing is a strategic indicative planning realized at the level of local self-government. The technology of territories development indicative plans building and clearing economic-legal imbalances is based on a definite degree of integration of regional and municipal government systems. Basic part of the plans are worked out and coordinated by regional bodies of state government and territory level plans are formed and implemented by administration of municipal units. A region role is in setting up a social-economic development strategy, planning, coordinating and colligation territorial plans on the basis of harmonization of budget streams. 
We understand indicative planning of municipal units sustainable development as a process of formation of system of meanings, characterizing the state and development of economy, and mechanisms for regulation of economy subjects activity, which provide reaching targeted markers and clearing imbalances in a economic-legal framework. A general concept of building an indicative plan for a agrarian region is given in figure 2 .

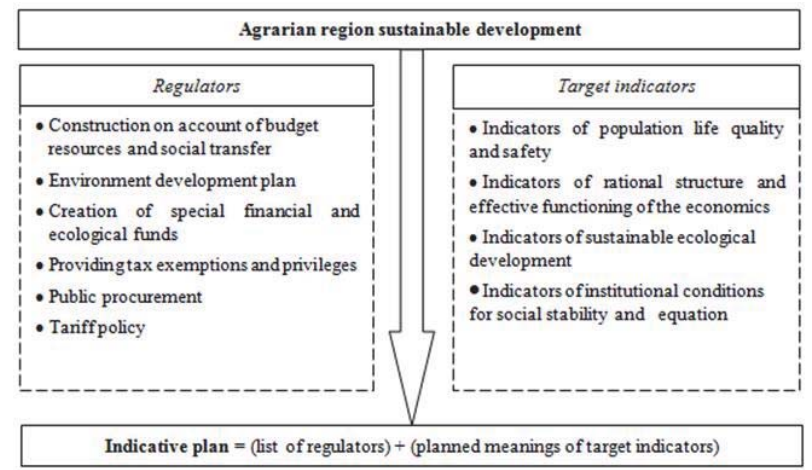

Figure 2 - Concept of indicative planning of agrarian region sustainable development (A. Tolon-Becerra, X. Lastra-Bravo, 2009).

\section{Conclusion}

The main "arena" for implementing principles and mechanisms of sustainable development into Russian practice of lifesustaining activity is the regions. It is they that have a vital demand in finding a complex solution of economic, social, demographic, and other problems. Region competitiveness increase will be promoted by more complete implementation of social-economic potential of municipal units (agrarian regions), by strengthening of local self-government institute on the basis of forming programmes of sustainable development in the light of regional specificity of territories.

At the same time to reach agrarian region sustainable development one can use the neoendogenous model offered, that promotes development of new ways in building strategies and complex local plans on the basis of indicative assessment of endogenous components and geotagging of external opportunities.

\section{Acknowledgment}

The article is prepared with financial support from Russian Foundation for Basic Research using the results of work on project №15-36-50216 "Development of methods of regulation of economic-legal system imbalance in the light of region economic security on the basis of evolutionary genetic approach implementation"

\section{References}

Ashley, C. and Maxwel, S.I. (2001) Rethinking Rural Development, Development Policy Review, Vol. 19, \# 4, pp.395-425.

Boudeville J.-R. (1966) Problems of Regional Economic Planning. Edinburgh.

Bourdieu, P. (2000) Les structures sociales de l'économie. Paris: Seuil. 293 p.

Cabus, P. (2001) The meaning of local in a global economy, European Planning Studies, Vol. 9, \# 8, pp.1011-1038.

Goodwin, M. (2003) Rural Governance: A Review of Relevant Literature, Paper prepared for Economic and Social. Research Council $(E S R C)$, Countryside Agency and Defra, University of Wales.

Hirczak, M. and Mollard, A. (2004) Quality of agricultural products and the environment: the case of Rhône-Alpes', Revue d'economie Régionale et Urbaine, Vol. 5, pp. 845-868.

Lowe P. (2006) European Agricultural and Rural Development Policies for the 21st Century // A New Rural Agenda. L.: IPPR. pp.. 29-45 Mantino F. (2008). Rural development in Europe. Policies, institutions and local actors from the '70s to today, II Sole 24 ore, Milan.

OECD (2007): The new rural paradigm. Policies and Governance, OECD Rural Policy Reviews, Paris.

Paus M. (2007) Collective agro-food initiatives and sustainable rural development: articulation between internal governance and rural governance: Swiss and Serbian cases. Paper Presented at the Meeting of PhD researchers. June 3-4, 2007. Geneva, Switzerland. 
Ploeg J.D. (2000) Revitalizing Agriculture: Farming Economically as Starting Ground for Rural Development. Sociologia Ruralis \# 40(4). pp.. 497-511.

Putnam R., Leonardi R., Nanetti R. (1993) Making democracy work : Civic traditions in modem Italy. Princeton: Princeton University Press. $258 \mathrm{p}$.

Ray, C. (2001) Culture economies: A perspective on local rural development in Europe, Centre for Rural Economy. Newcastle upon Tyne.

Reed, M.S. Fraser, D.G. and Dougill, A.J. (2006) An adaptive learning process for developing and applying sustainability indicators with local communities, Ecological Economics, Vol. 59, pp.406-418.

Shortall, S. (2008) Are rural development programmes socially inclusive? Social inclusion, civic engagement, participation, and social capital: Exploring the differences, Journal of Rural Studies, Vol. 24, pp.450-457.

Shucksmith, M. (2000) Endogenous Development, Social Capital and Social Inclusion: Perspectives from LEADER in the UK, Sociologia Ruralis, Vol. 40, \#2, pp.208-218.

Sucháček J. and Malinovský J. (2007) Regional Development in Transitional Economies after 1989: Reformation or Deformation?. Paper Presented at the 47th Congress of the European Regional Science Association. August 29th - September 2nd, 2007. Paris, France.

Tolon-Becerra A., Lastra-Bravo X. (2009) Planning and neo-endogenous model for sustainable development in Spanish raral areas. Spain: University of Almeria. Area of Engineering Project. $16 \mathrm{p}$.

Ward, N. Atterton, J. Kim, T. Lowe, P. Phillipson, J. and Thompson, N. (2005) Universities, the Knowledge Economy and "NeoEndogenous Rural Development", Centre for Rural Economy Discussion, Paper Series \# 1. 